\title{
Length - Weight Relationship of A Riverine Fish Barilius barila (Gunther) Dahare Rajesh
}

\begin{abstract}
The length-weight relationship of a fish Barilius barila (Gunther) was studied which was collected from Wainganga river located $20^{\prime} 48^{\circ} \mathrm{N} 79^{\prime} 38^{\circ} \mathrm{E}$. The entire length-weight data were analyzed by least square method. The lengthweight relationship of Barilius barila was studied in 258 fishes under three categories as male, female and common. Their corresponding parabolic representations are male $\mathrm{B}$. barila $\mathrm{W}=0.008167 \mathrm{~L}^{2.8829}$, female $B$. barila $\mathrm{W}=0.005931$ $\mathrm{L}^{3.1223}$ and common $B$. barila $\mathrm{W}=0.006415 \mathrm{~L}^{3.0373}$. The equilibrium constant ' $\mathrm{b}$ ' is found to be 2.8829 in males, 3.1223 in females and 3.0373 common. The females are heavier than males at equal length. The equilibrium constant does not obey the cube law because it deviates from 3 . The value of common fish was found to be more than 3 indicates the environment of Wainganga river was good for healthy development of fishes.
\end{abstract}

Keywords: Length-weight relationship; Barilius barila; Riverine fish

\section{Introduction}

World facing the problem of proteinous food material and fish is one of the major sources of protein rich food. World's one sixth animal protein comes only from fish. As far as India is concerned, there is an increase in the population rate as compare to food production rate and due to that there is a problem of protein deficient malnutrition. Almost nearly $34^{\text {th }}$ of our population is suffering from the same problem. If the fish is used as food for more extent the problem of malnutrition can easily be solved. Hence fishery production becomes the matter of more concern.

For increasing the production of fish in both marine and inland area of water it is essential to explore water resources. Infact the world fish production is about $90 \%$ in marine and $10 \%$ in inland water. In India this ratio is 60 and 40 percent respectively. To develop the fish industry it has become very essential to know the biology of fish for satisfactory management. The length-weight relationship is one of the important parameter in biology of fish. According to [11] the weight of the fish proportionately increases to the length of fish. If the value of equilibrium is constant, it is 3. It means fish obeys the cube law [8]. But the physical and chemical factor affects the growth and changes the value of equilibrium constant ' $b$ '.

\section{Materials and Methods}

The fishes Barilius barila were collected from Wainganga River at Pauni, Bhandara district, Maharashtra located at $20^{\prime} 48^{\circ} \mathrm{N} 79^{\prime} 38^{\circ} \mathrm{E}$. The random samples were collected of variable lengths. Fishes were brought to laboratory as for as possible in fresh condition and preserved in $10 \%$ formalin. The lengths of the fishes were measured from their tip of the snout to the last ray of the caudal fin in centimeter. After measuring the fishes, they were weighed on a single pan balance of 0.1 sensitivity. The sex of each fish was determined after giving an incision on midventral line. They were categorized in the group of 0.5 centimeters and data obtained was fitted to the formula $\mathrm{Y}=\mathrm{a}+\mathrm{bX}$ in order to test the difference between regression coefficient for male, female and common.

\section{Results and Discussion}

The length-weight relationship was expressed in the equation $\mathrm{W}$ $=\mathrm{a} \mathrm{L}{ }^{\mathrm{b}}$ where as, $\mathrm{W}$ and $\mathrm{L}$ represents weight and length of fish, ' $\mathrm{a}$ ' is the initial growth index and ' $b$ ' is the equilibrium constant. In the present study 258 fishes comprising 123 males and 135 females ranging from $3.8 \mathrm{~cm}$ to $9.1 \mathrm{~cm}$ and weight 3.8 to 9.0 gm were utilized. The data of length-weight relationship of Barilius barila was categorized in three groups i.e., male, female and common.
The general equation $\mathrm{W}=\mathrm{a} \mathrm{L}^{\mathrm{b}}$ can be written as $\log \mathrm{W}=\log \mathrm{a}+$ $b \log L$ i.e., $Y=a+b X$. The linear equation was fitted separately and the logarithmic equation of the length-weight relationship in Barilius barila found to be

\begin{tabular}{|ll|}
\hline Male Barilius barila & $\log Y=-2.0879+2.8879 \log X$ \\
\hline Female Barilius barila & $\log Y=-2.2269+3.1223 \log X$ \\
\hline Common Barilius barila & $\log Y=-2.1928+3.0373 \log X$ \\
\hline
\end{tabular}

Their corresponding parabolic form of equation is

\begin{tabular}{|ll|}
\hline Male Barilius barila & $\mathrm{W}=0.008167 \mathrm{~L}^{2.8829}$ \\
\hline Female Barilius barila & $\mathrm{W}=0.005931 \mathrm{~L}^{3.1223}$ \\
\hline Common Barilius barila & $\mathrm{W}=0.006415 \mathrm{~L}^{3.0373}$ \\
\hline
\end{tabular}

Hence the cubic formula $\mathrm{W}=\mathrm{a} \mathrm{L}^{\mathrm{b}}$ represents the length-weight relationship for Barilius barila is not proper. The value of ' $\mathrm{b}$ ' variable was 2.8879 in males, 3.1223 in females and 3.0373 common. These values did not obey the cube law because values were deviating from 3 . The significance of variation for length-weight relationship of Barilius barila was carried out and these were not significant at $5 \%$ level.

The length-weight relationship was studied by many workers in variable fishes in India and abroad like [8] in Lencicthys artadi, [1] in Salmon trutta, [3] in Tuna, [2] in Sardinella longicep, [4] in Labeo gonius, [7] in Oreochromis mossambicus, [6] in Liza tade, [5] in Chela bacaila.

In length-weight relationship the growth coefficient ' $b$ ' of the fish should be close to 3.0. It may range between 2.4 and 4.0 as reported by $[8,12,5]$. The value of ' $b$ ' in females was higher than the males as reported by $[9,10,5]$. The difference in the ' $b$ ' value of male and female indicated that the females were heavier than the males of the same length. In Barilius barila the value of 'b' is 2.8829 in males and 3.1223

${ }^{*}$ Corresponding author: Dahare Rajesh, Zoology department, Sarvodaya Mahavidyalaya, Sindewahi, Dist. Chandrapur 441222, Maharashtra, India, E-mail: drrajeshdahare@gmail.com

Received May 01 2011; Accepted June 29 2011; Published July 042011

Citation: Rajesh D (2011) Length - Weight Relationship of A Riverine Fish Barilius barila (Gunther). J Aquac Res Development 2:115. doi:10.4172/21559546.1000115

Copyright: (c) 2011 Rajesh D. This is an open-access article distributed under the terms of the Creative Commons Attribution License, which permits unrestricted use, distribution, and reproduction in any medium, provided the original author and source are credited. 
Citation: Rajesh D (2011) Length - Weight Relationship of ARiverine Fish Barilius barila (Gunther). J Aquac Res Development 2:115. doi:10.4172/21559546.1000115

in females and common is 3.0373. It means the value of ' $b$ ' in males was less than the cube law and females was more than the cube law, while the commons value was found to be more than 3 . It indicates the environment of Wainganga River was found good for healthy development of fishes.

\section{Acknoledgement}

The author thanks to Dr. A.G. Sontakke, Ex. Director, Institute of Science, Nagpur for facilities and guidance.

\section{References}

1. Allen KR (1938) Some observations on the biology of the trout (Salmo trutta) in windermere. J Ani Ecol 7: 333-349.

2. Antony Raja (1967) Length-weight relationship in the oil sardine, Sardinella longiceps Val. Indian J Fish 14: 159-170.

3. Bell RR (1963) Length-weight relationship for blue fin tuna in the California fishery. California Div Fish and Game.

4. Chatterii A (1980) The relative condition factor and length-weight relationship of the fresh water carp Labeo gonius (Ham) Cyprinidae teleost. J Bombay Nat Hist Soc 77: 435-443.
5. Dahare RB, Dhamani A (2009) Length-weight relationship of a freshwater fish Chella bacaila (Gunther). Nat Sem on ETICLSEC: 79.

6. Das SK (2004) Biology of length-weight and condition in a brackish water fish Liza tade (Forskal). Indian J Env Ecopla 8: 209-211.

7. Hatikakoty G, Biswas SP (2004) Length-weight relationship and condition factor of Oreochromis mossambicus (Peters) from a domestic pond Nazira upper Assam. Indian J Env And Ecoplan 8: 220-236.

8. Hile R (1936) Age and growth of the Cisco Leucichthys artedi (Le Suur) in the lake of three northern highland Wisconsin Bull. US Bur Fish 48: 209-317.

9. Homiara SJ (1992) Biology and population dynamics of the cat fish Arius jella from the Karnafully river estury Chittagong. MSc Thesis Chillagong university Bangladesh.

10. Kulshrestha SK, Srivastava M, George MP (1993) Length-weight relationship of a major carp Catla catla (Ham.) from two water bodies of Bhopal. Adv Limnol: 329-332.

11. Le Cren ED (1951) The length-weight relationship and seasonal cycle in gonadal weight and condition in perch (Perca fluviatilis). J Animal Ecol 20: 201219 .

12. Martin WR (1949) The mechanics of the environmental control of body from in fishes. Univ Toronto Styd Biol 58: 1-91. 